SECTION 4. Computer science, computer engineering and automation.

Korneev Andrey Mastislavovich

associate professor

Lipetsk state technical university, Russia weenrok@mail.ru

Devin Alexander Pavlovich post-graduate student Lipetsk state technical university, Russia devin-ap@outlook.com
Mirsaitov Gregory Rashitovich undergraduate student Lipetsk state technical university, Russia mirsaitov31@,yandex.ru

Knjasev Maxim Andreyevich undergraduate student Lipetsk state technical university, Russia magmel.programmer@gmail.com

\title{
FUNCTIONAL STRUCTURE OF THE AUTOMATED SYSTEM OF THE CHOICE OF OPTIMUM PRODUCTION MODES
}

\begin{abstract}
Functional structure of the automated system selection of optimum production modes is described in this article. By the example of beer enterprise the basic methods of designing such systems are reviewed. The main stages of beer production are named and technological processes are determined.
\end{abstract}

Key words: automated system, optimal regimes, discrete process, modeling of technological processes.

Due to the competition extension, the quality of production comes out on top, and, therefore, the quality of technology. Profitability of any production, steady providing the set indicators of quality are hard to achieve without the automated control of technology and flexible management of it. Due to the lack of the theoretical models, which reflect connection of technology with quality, the models received on the basis of empirical data are usually used. Complexity of production processes allows to assume that connection between technology factors and output properties (and value of each factor can influence a greater or lesser extent for the outcome characteristics) can have difficult structure.

The developed automated system of a choice of optimum production modes allows to receive production coming most nearer to set quality by change of technological conditions of processing of a semi-product at the subsequent stages on the basis of information on previous technology. This system provides not only the problem decision of a choice of optimum technology, but also modeling of technological processes, their statistical analysis.

Heterogeneity of the equipment and rigging of the modern enterprise, diversity of technological preparation, production make a choice of optimum methods and sequence of production impossible without use of the automated systems of technological preparation of production, especially at design of technological processes.

As an example we will take the enterprise for production of beer. As the production technology of beer is that initial materials turn into a ready-made product for some main technological stages including giving of raw materials and crushing, jam preparation, a jam filtration, cooking of a mash, cooling of a mash, mash fermentation, a filtration of beer and necessity of establishment of connection between technology and final characteristics is an important task.

Besides, because the production technology is set by the indication of ranges of the technology factors influencing final properties of production, the problem of a choice of optimum technology is reduced to finding of these ranges in the considered technological space guarantees obtaining demanded characteristics. For the solution the criterion of communication information of technology and characteristics of the finished goods, counted on the basis of experimental data is used. Physical and chemical characteristics of production, 
density, chromaticity, the content of alcohol, contents $\mathrm{CO} 2$ are the most part of indicators of quality of beer regulated by standards. They depend on factors of technology and are formed at all stages. Lack of unambiguous functional dependences between factors of technology and indicators of quality of ready beer, existence of the random variables influencing technological process and final properties, have resulted in need of technology specifying in the form of the competent intervals for each factor.

Researches showed that level of output properties is defined by values of the chosen ranges, and for obtaining high consumer characteristics it is necessary to solve a problem of a choice of optimum ranges for technology factors. For this purpose it is necessary to pick up criterion by means of which it is possible to allocate the borders of each factor allowing with the maximum probability to receive demanded properties. As criterion for the solution of an objective the measure of information quality who allows to consider probability of hit in studied range at existing technology is used, and also includes information, about efficiency of technological modes which didn't get to studied range. Considering various and comparing them by means of the chosen criterion, it is possible to allocate such technology for which it will have the maximum value.

Production of beer refer to a class of the continuous and discrete. It means that the portion of production which is processed by sequence of technological units can be allocated separately. Tracking movement of every portion and change of its physical and chemical properties can be carried out. On the other hand the majority of units work in continuous process during which in it separate portions of production are consistently set. Continuous and discrete nature of process of production of beer demands the accounting of its specific features in a projected control system.

The ready-made product of any production is delivered to consumers according to requirements of GOST (a set of state technical standards), branch and intersectoral specifications, and also intra factory specifications (enterprise standards), which regulate requirements to a semi-product by its transfer from one shop in another for the subsequent stage.

Main stages of technological process of beer production:

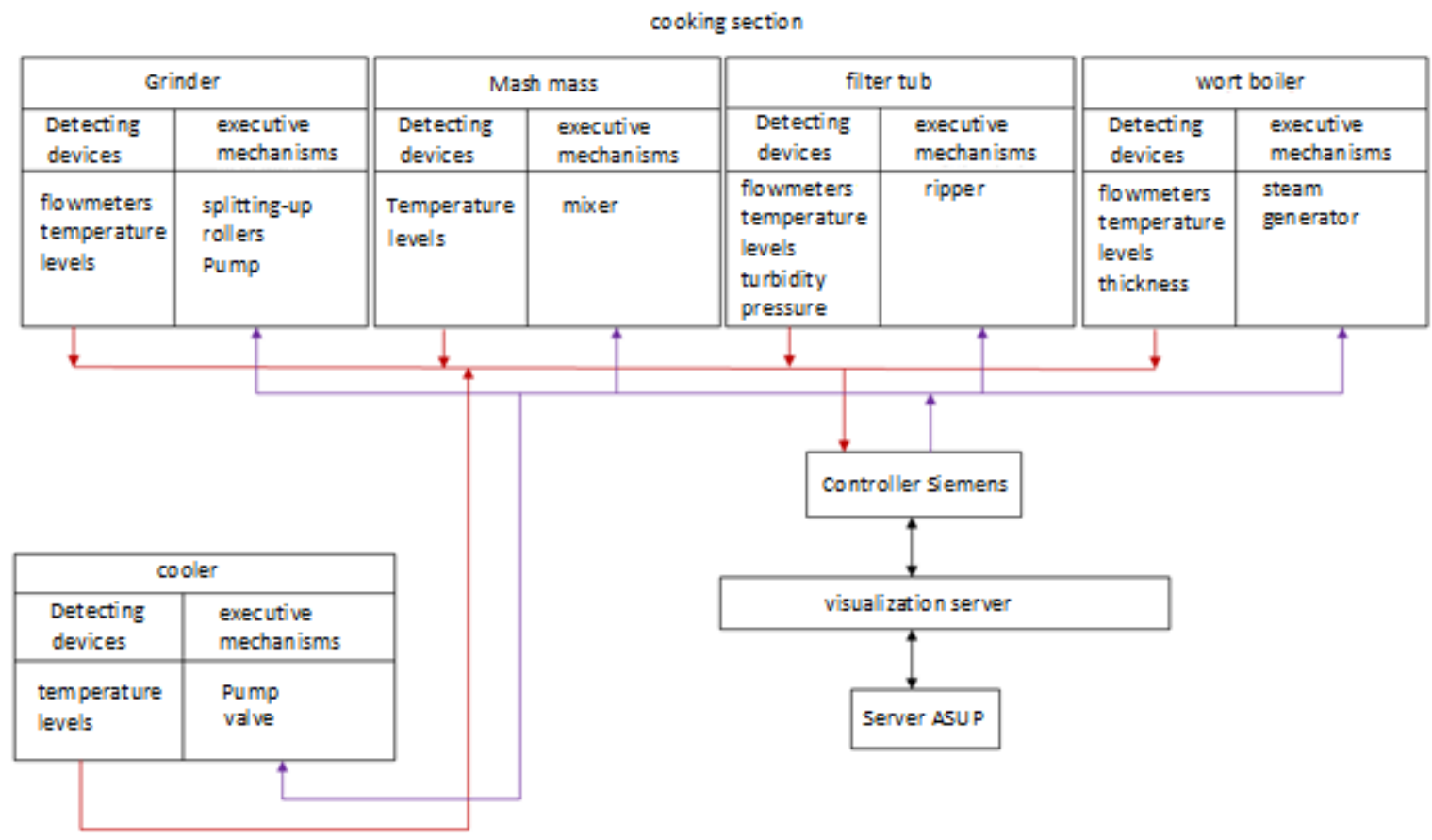

Figure 1 - Block diagram of cooking section. 


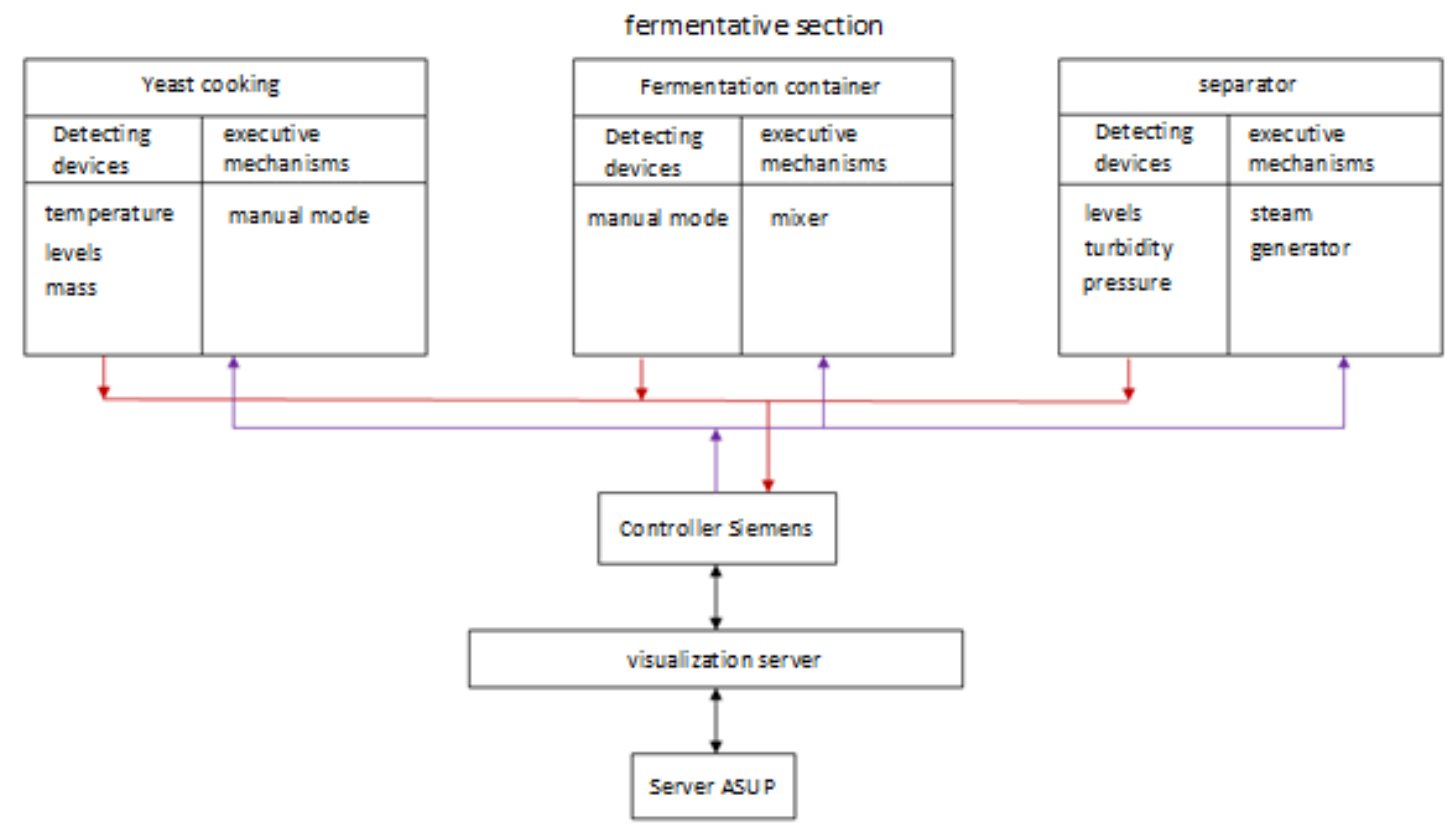

Figure 2 - Block diagram of fermentative section.

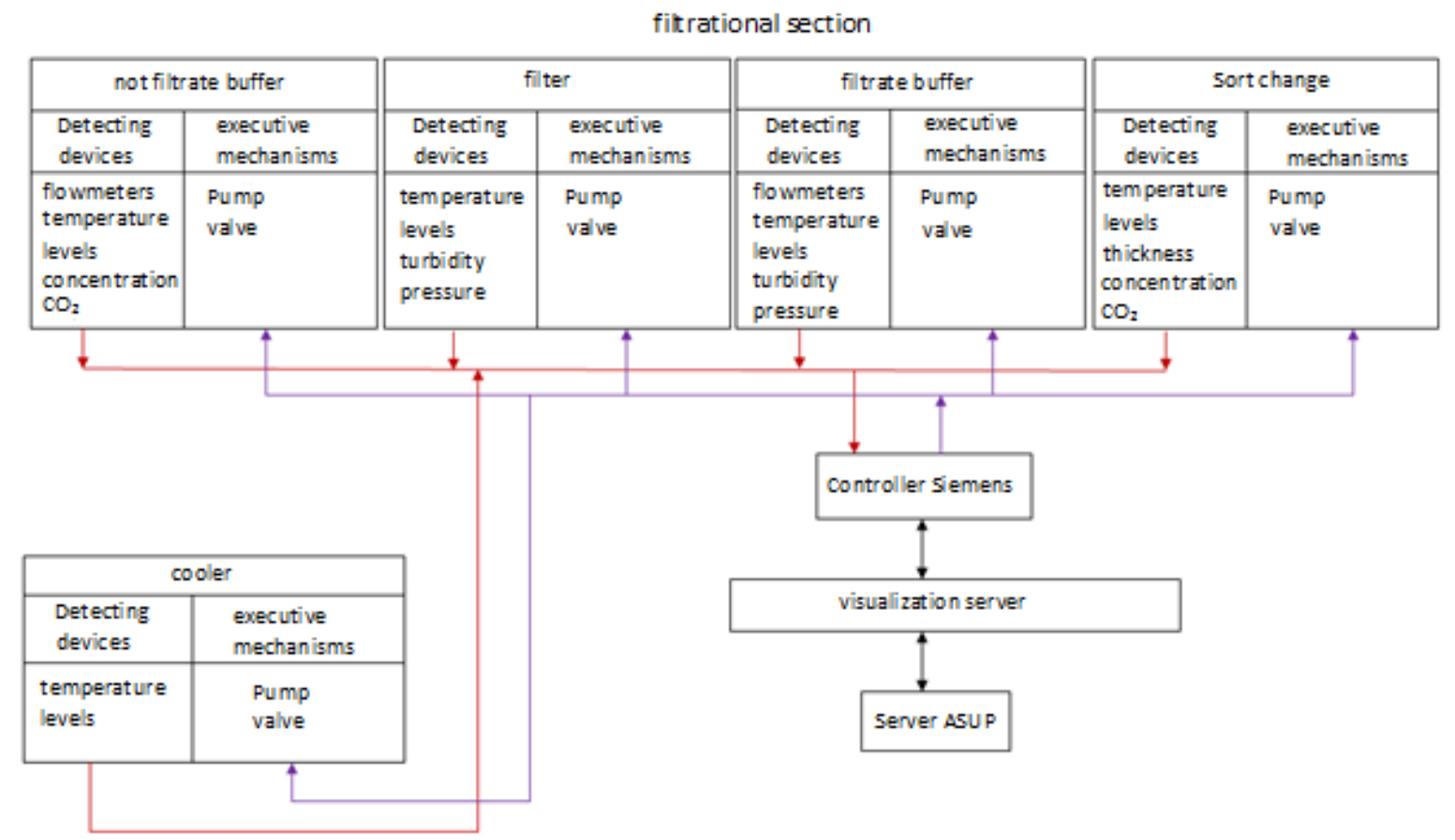

Figure 3 - Block diagram of filtrational section.

According to specific aims and problems of management the following functional subsystems have to be a part of the developed automated system:

- subsystem of input of basic data;

$\circ$ provides opening of files of databases and reading necessary information (standards for the weekend properties);

○ provides check of a correctness, logical integrity of the loaded data; 
○ realizes formation of initial approach of technological borders on the basis of only a few data;

- subsystem of calculation of criterion of an assessment technology;

o calculation of criterion of an assessment technology, based on use of uncertainty (entropy) of connection between realization of the production technology and final quantities;

- calculation of criterion of an assessment of the technology, based on use of uncertainty (entropy) of connection between realization of the production technology and final properties with penal coefficients;

- calculation of criterion of an assessment of the technology, considering splitting output properties of end products on quality categories;

- subsystem of rough control of technological borders;

- realizes algorithm of a range assessment of quality (such borders of ranges are made for each factor that the same number of measurements got to each of them) and ways of division of technological space;

- realizes algorithm of simultaneous division of technological space of all factors on equal parts and its conditions, and, therefore, and an optimality of received $\mathrm{N}$ - a measured subspace;

o provides search of optimum technological borders with different methods;

- subsystem of basic technological space definition

$\circ$ provides the analysis of the optimum technological subspaces revealed at a stage of rough control, for the purpose of the best usage - basic (within the chosen criterion) at the subsequent stage of optimization of technological borders; as a result, the best ranges are made for each factor at this stage;

- subsystem of exact control of technological borders;

- realizes algorithm of correction of the chosen basic technology (shift of borders);

- $\quad$ subsystem of formation of results;

0 provides representation of results of work of system in the look clear and userfriendly (schedules, histograms, tables).

The structure of a control system is presented by technological process in figure 4 .

The developed automated system of a choice of optimum modes of production of beer allows to carry out function of the assistant in situations of emergence of defects. This function consists in issue of recommendations about transfer of beer to other sort (on one of fabrication stages), more suitable for this structure and characteristics. The content of alcohol or chromaticity can be examples. 


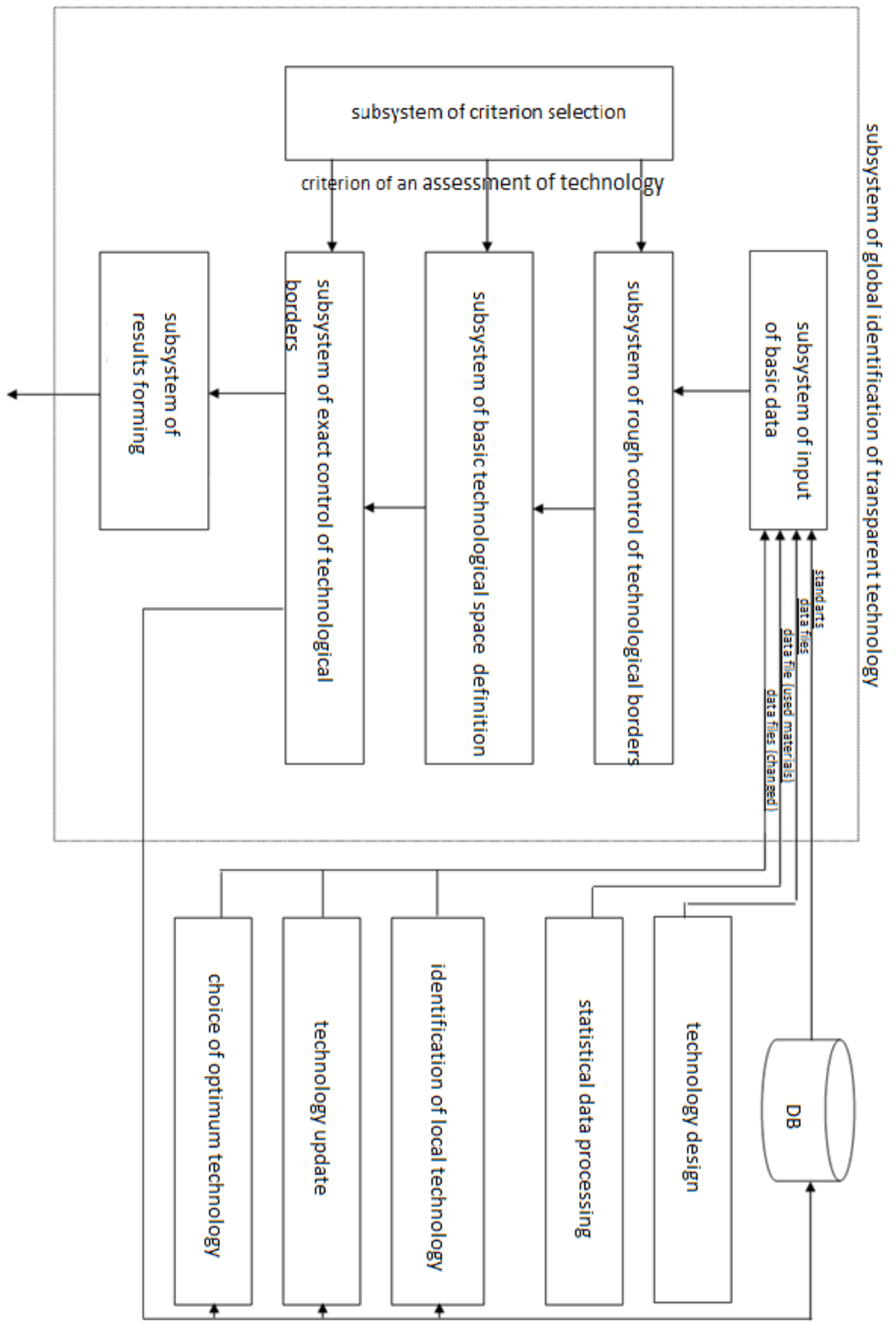

Figure 4 - Functional structure of system. 


\section{Bibliography}

1. Корнеев А.М., Блюмин С.Л., Сметанникова Т.А. Численные методы поисковой оптимизации дискретных клеточно-иерархических систем [Текст] / Корнеев А.М., Блюмин С.Л., Сметанникова Т.А. // Вести высших учебных заведений Черноземья. - 2013. - №3. - C. 21-26.

2. Korneev A.M., Abdullah L.S. Automated system for the design process and the generation of technological information // International Scientific Journal, Theoretical \& Applied Science. «Advances in techniques \& technologies», Milan, Italy. - №10, 2013. c. 4144.

3. Korneev A.M., Al-Saeedi F.A., Al-Sabry G.M., Smetannikova T.A., Nagi A.M. Discrete modeling of complex manufacturing systems // International Scientific Journal, Theoretical \& Applied Science. «Economy, technology, education and prospects for 2014», Malmö, Sweden. - №1, 2014. c. 32- 35.

4. Korneev A.M., Veselovskaya N.A., Ivanov A.V. Statistical estimation of irregular form technologic space on 2n-trees basis// Proceedings of the 4rd International Academic Conference «Applied and Fundamental Studies» Vol. I ,St. Louis, Missouri, USA . 2013,c.199-202.

5. Korneev A.M., Ziyautdinov V.S., Zolotareva T.A., Smetannikova T.A. The description of a technology with using iterative networks // "Science, Technology and Higher Education" 2nd international scientific conference, Vol. II, Westwood, Canada, 2013, p.159 163.

6. Корнеев, А.М. Использование итеративных цепей для описания многостадийных пространственно-распределенных производственных систем [Текст]/ А.М. Корнеев, В.Н. Малыш, Т.А. Сметанникова // Вестник Российского университета дружбы народов. Серия: Инженерные исследования. - 2012. - №2. - С. 78-84.

7. Корнеев, А.М. Методы идентификации сквозной технологии производства металлопродукции [Текст]: монография / А.М. Корнеев; Липецкий государственный педагогический университет. - Липецк: ЛГПУ, 2009. - 286 с.

8. Корнеев А.М., Мирошникова Т.В. Методика поиска оптимальных границ факторов сквозной технологии. Системы управления и информационные технологии. 2008, №3(33), c.93-96.

9. Блюмин С.Л., Корнеев А.М. Дискретное моделирование систем автоматизации и управления [Текст]: Монография; Липецкий эколого-гуманитарный институт. - Липецк: ЛЭГИ, 2005, - 124 с.

10. Кузнецов Л.А., Корнеев А.М. Автоматизированная система выбора оптимальной технологии производства проката. - Известия вузов. Черная металлургия, 1994, №5, c.45-48. 